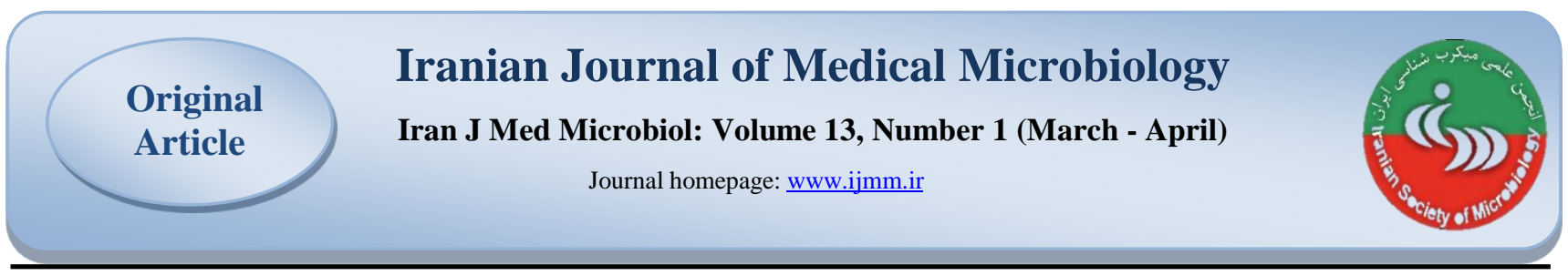

\title{
Determination of PCR-ELISA Diagnostic Value in Comparison With Classical Methods and PCR to Detect Resistance to Methacillin
}

\author{
Susan Rezavand ${ }^{1}$, Jafar Amani2 ${ }^{*}$, Neda Akbari ${ }^{1}$, Hamid Reza Mohajerani ${ }^{1}$, \\ Shahram Nazarian ${ }^{3}$, Hamideh Mahmoodzadeh Hosseini ${ }^{2}$, Mehrdad Moosazadeh Moghaddam ${ }^{4}$ \\ 1. Department of Biology, Faculty of Basic Sciences, Arak Branch, Islamic Azad University, Arak, Iran \\ 2. Applied Microbiology Research Center, Systems Biology and Poisonings Institute, Baqiyatallah University of Medical Sciences, Tehran, Iran \\ 3. Department of Biology, Faculty of Basic Sciences, Imam Hussein University, Tehran, Iran \\ 4. Applied Biotechnology Research Center, Baqiyatallah University of Medical Sciences, Tehran, Iran
}

\section{Article Information}

\section{Article Subject: \\ Molecular Microbiology}

DOI: 10.30699/ijmm.13.1.22

Corresponding author:

\section{Dr. Jafar Amani}

Applied Microbiology Research

Center, Systems Biology and

Poisonings Institute, Baqiyatallah

University of Medical Sciences,

Tehran, Iran

Email:

jafar.amani@gmail.com

Use your device to scan and read the article online

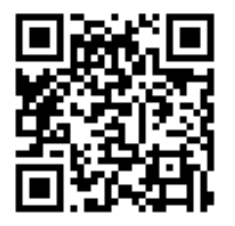

\section{Abstract}

Background and Aims: High prevalence of Methicillin Resistant Staphylococcus Aureus isolates (MRSA) as well as the multi-drug resistance in this bacterium causes difficulties in the treatment of infections due to these bacteria. Hence, detection of MRSA isolates by rapid and accurate methods is necessary. PCR-ELISA is an accurate and molecular technique that is used for the detection of several pathogens. The aim of this study is the detection of MRSA using PCRELISA.

Materials and Methods: Specific primers for mecA gene were designed. Then, dNTP labeled with Digoxigenin was applied for amplifying $m e c A$ gene. DIG-labeled PCR products were seeded on the well coated streptoavidin and identified by anti-DIG-peroxidase conjugate. Furthermore, Biotin-labeled DNA probe specific for mecA gene was used. Sensitivity and specificity of the method was determined. Resistance to methicillin among 70 clinical isolates was determined by the disk diffusion, agar dilution and PCR-ELISA methods.

Results: $M e c A$ gene of $S$. aureus was amplified using gene specific primers resulted in a fragment with 310 bp length. Findings from the PCR-ELISA technic showed no cross-reactivity with Klebsiella Pneumoniae, Bacillus subtilis and Esheriashia coli as control bacteria and its sensitivity was $0.5 \mathrm{ng}$. The prevalence of MRSA clinical isolates by the disk diffusion, agar dilution and PCR-ELISA methods was $60 \%, 58.5 \%$ and $60 \%$, respectively.

Conclusion:The PCR-ELISA technique was known as an accurate and rapid test for the detection of infection agents using their specific gene. This technic can applied as an appropriate alternative method for time-consuming, less sensitive and expensive techniques such as Real-time PCR and differential biochemical tests which are currently used in laboratory.

Keywords: Staphylococcus aureus, Antibiotic resistance, PCR-ELISA, mecA gene

Received: 2017/12/19 Accepted: 2019/06/22 Available online: 2019/07/01

Copyright $\odot 2019$ Iranian Journal of Medical Microbiology. This is an open-access article distributed under the terms of the Creative Commons Attribution License (http:///creativecommons.org/licenses/by/4.0), which permits unrestricted use, distribution, and reproduction in any medium, provided the original work is properly cited.

How to cite this article: 


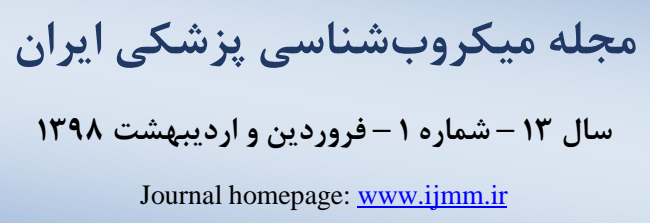

\title{
PCR-ELISA نسبت به روشهاى كلاسيك و PCR براى شناسايى سويههاى
}

\author{
استافيلوكوكوس اورئوس مقاوم به متىسيلين \\ سوسن رضاوند'، جعفر امانى ז" ، ندا اكبرى'، حميدرضا مهاجرانى'؛

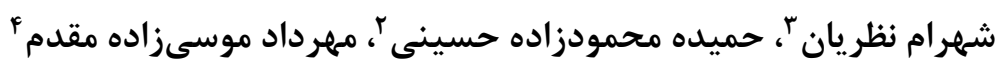

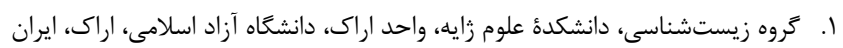

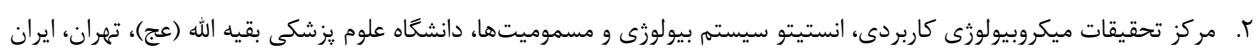

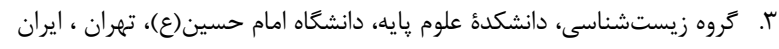

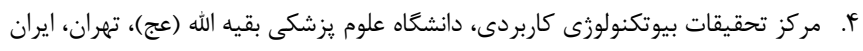

\section{جكيده}

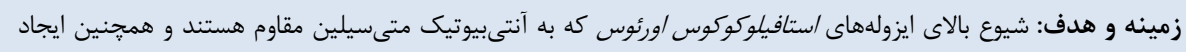

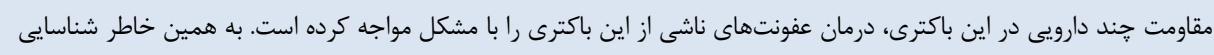

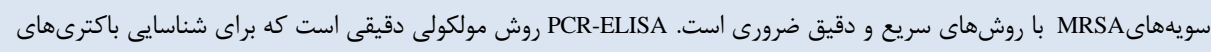

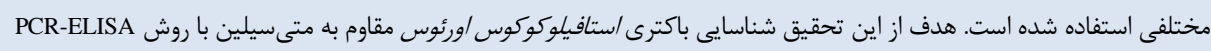

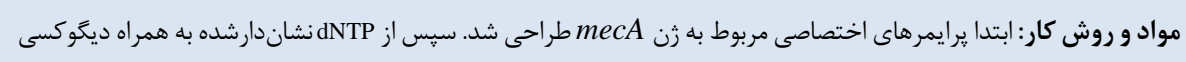

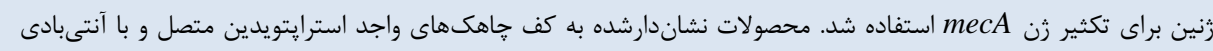

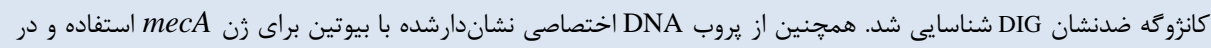

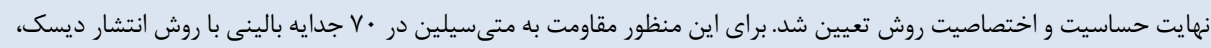

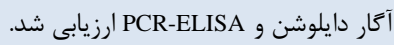

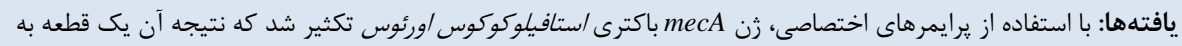

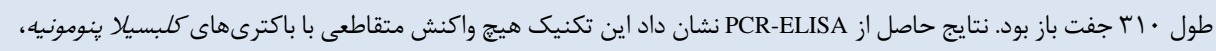

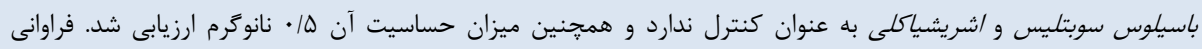

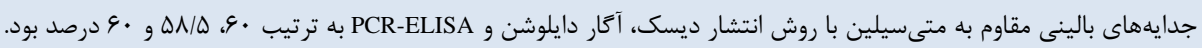

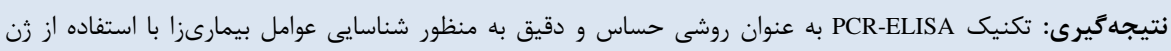

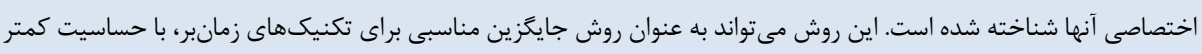

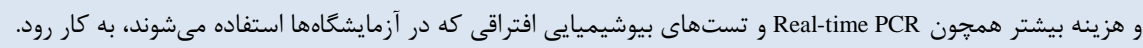
كلمات كليدى:/ستافيلوكوكوس /ورئوس، مقاومت آنتىبيوتيكى، PCR-ELISA، زن mecA كيىرايت C) مجله ميكروبشناسى بزشكى ايران: دسترسى آزاد؛ كبىبردارى، توزيع و نشر براى استفاده غيرتجارى با ذكر منبع آزاد

\section{اطلاعات مقاله}

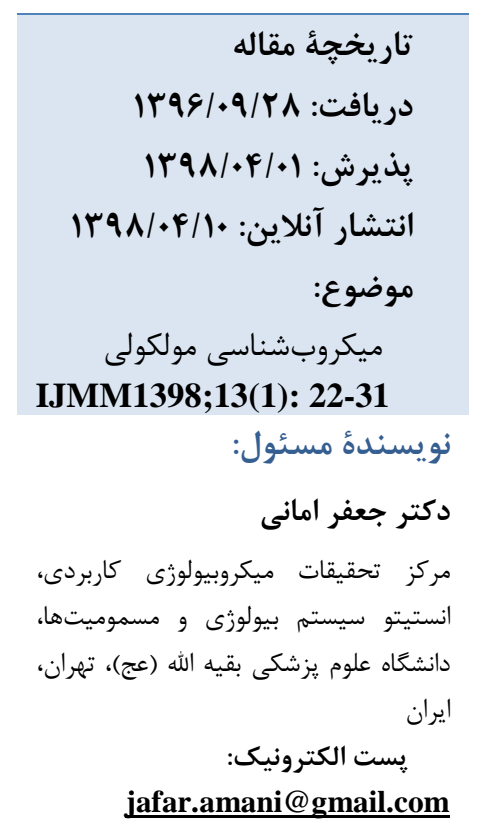

مقامه

توكسينها، تهاجم مستقيم و تخريب بافتها، تظاهرات بالينى مختلفى

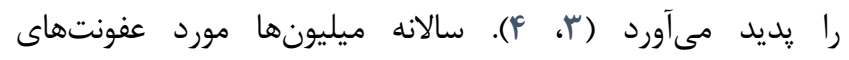
استافيلوكوكى در سراسر جهان كزارش مىشود. با توجه به قدرد

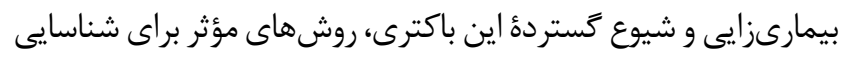

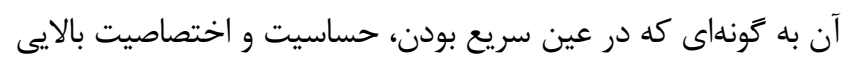

استافيلوكوكوس اورئوس از جمله مهمترين عوامل ايجادكننده

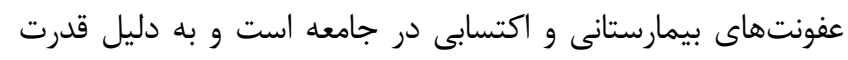

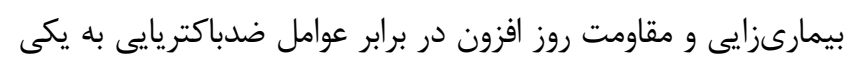

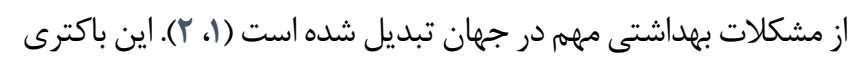
توانايى ايجاد طيف وسيعى از بيمارىها را دارد و از طريق توليد انواع 


\section{مواد و روشها \\ سويههاى باكتريايى و محيطهاى كشت}

براى اين منظور سويه استاندارد باكترى /ستافيلوكوكوس /ورئوس

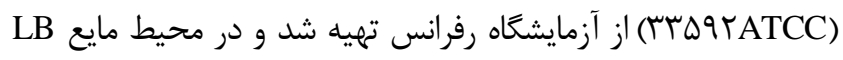

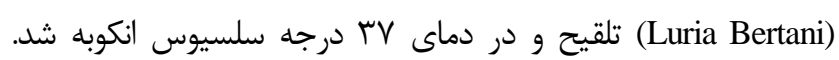

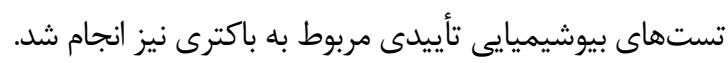

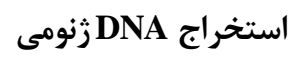

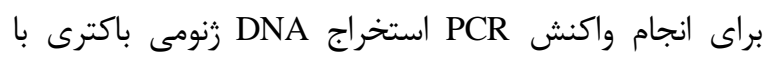

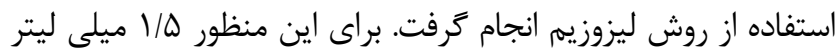

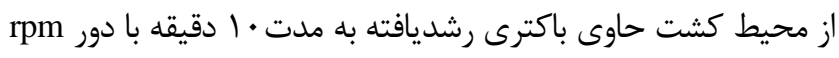

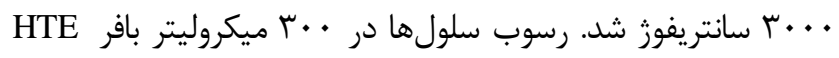
يكنواخت شد و •ه ميكروليتر ليزوزيم (High Tris-EDTA) • • (mg/ml)

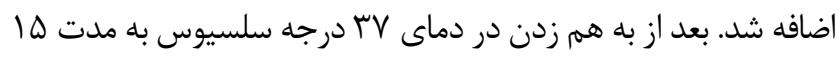

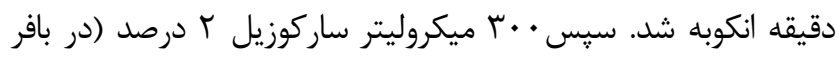

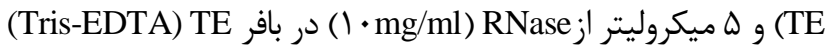

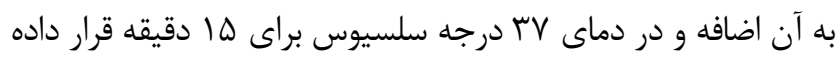

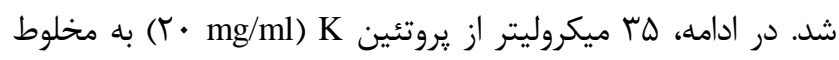
واكنش اضافه و در Tr درجه سلسيوس به مدت • r دقيقه انكوبه شد.

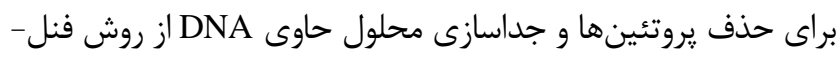

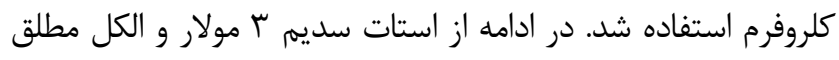

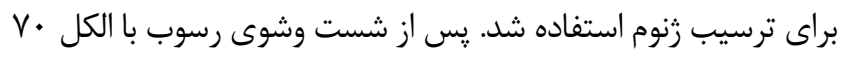

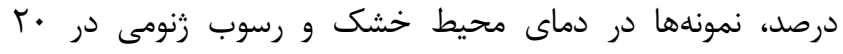

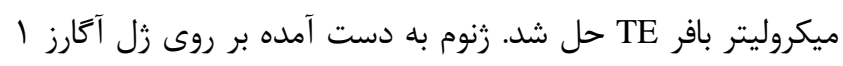

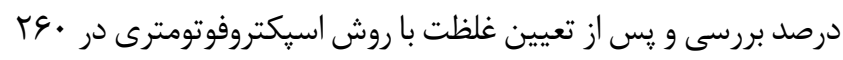
نانومتر براى مراحل بعدى كار استفاده شد.

\section{واكنش PCR}

به منظور تكثير قطعه رنى، يك جفت يرايمر اختصاصى طراحى

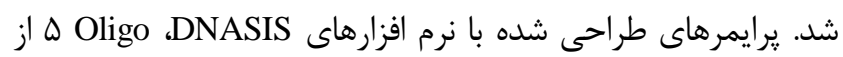
نظر TM، Th، تشكيل لوب و يرايمر دايمر بررسى شدند (جدول (1).
نيز داشته باشد حائز اهميت است. يكى از مشكلات اصلى در بيمارى

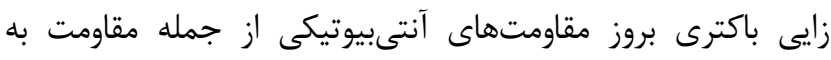

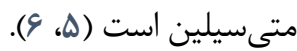
هر حند در سالهاى اخير روشهاى متعددى براى شناسايى

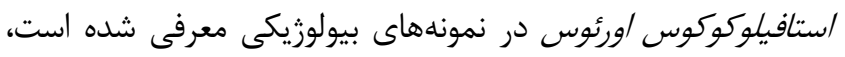

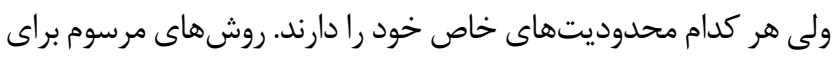
تشخيص /ستافيلوكوكوس /ورئوس در نمونهاى بالينى، محيطهاى

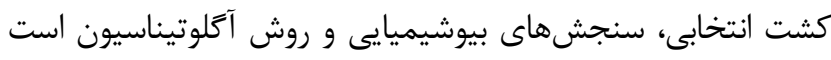

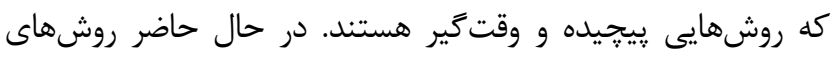

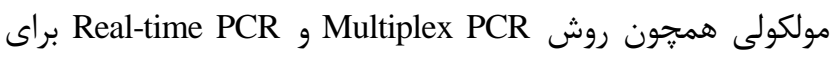

شناسايى باكترى /ستافيلوكوكوس /ورئوس استفاده مىشود (V-V) (9).

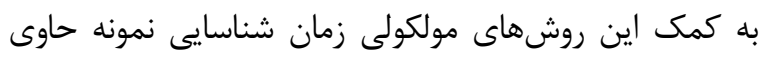

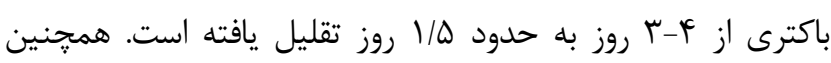
روشهاى PCR حساسيت كمى دارند و نيازمند كشت نمونهاى باى بالينى

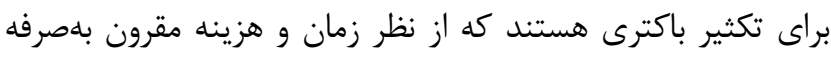

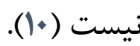

از ديخر روشهاى تشخيص، كيتهاى مبتنى بر آنتىبادىهاى منوكلونال هستند كه هر جند اختصاصيت زيادى دارند، اما از لحاظ

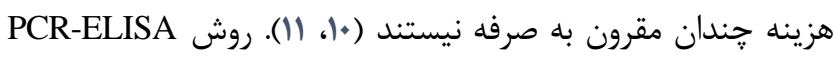

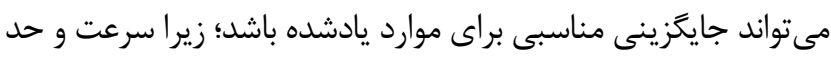
تشخيص قابل قبولى را در شناسايى مقادير اندك توالى هاى اختصاصى زن بيمارى فراهم مى آورد. استفاده از ديخوكسى رنين (Digoxigenin) نيز يك روش تشخيص مناسب و غير راديواكتيوى براى تشخيص

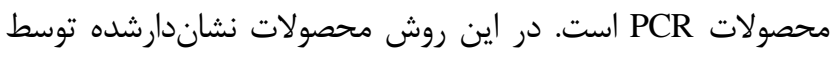

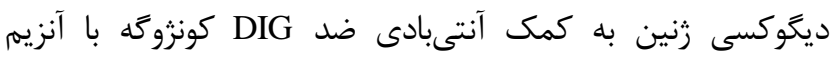

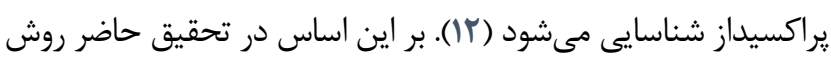
PCR-ELISA اختصاصى به همراه ديكوكسىزنين محصولات PCR نشاندارشده، زن mecA در باكترى /ستافيلوكوكوس /ورئوس تشخيص دمدئ داده شود.

جدول ا. يرايمرها و يروب طراحىشده از زن mecA

\begin{tabular}{|c|c|c|}
\hline 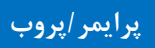 & توالى نوكلئوتيد & تعداد نوكلئوتيد \\
\hline$m e c \mathrm{~F}$ & GAAATGACTGAACGTCCGATA & ا آباز \\
\hline mec $\mathrm{R}$ & CCAATTCCACATTGTTTCGGTCTAA & 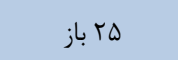 \\
\hline mec $\mathrm{P}$ & Biotin-AACATTGATCGCAACGTTCA & 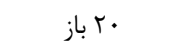 \\
\hline
\end{tabular}




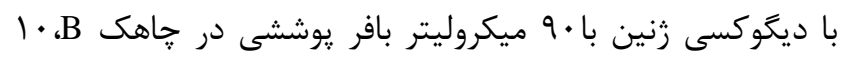

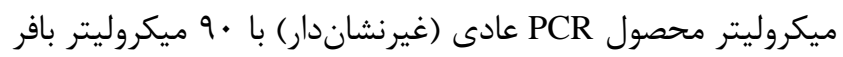

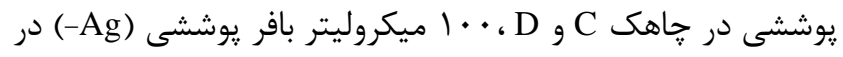

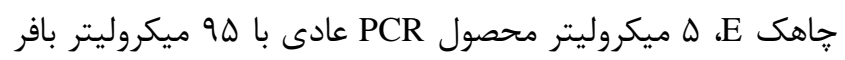

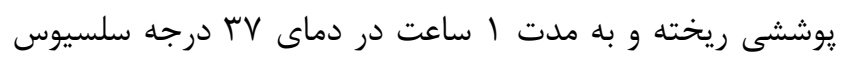

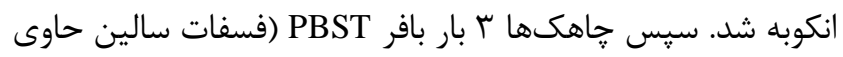
ه• • • درصد تويين) شستوشو داده شد. در مرحله بعد به هر كدام

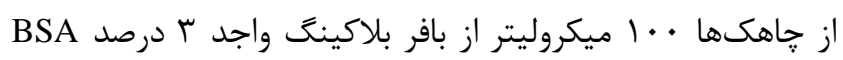
اضافه و Pavine serum albumin) سلسيوس انكوبه شد. در ادامه خاهكها همانند مرحله قبلى

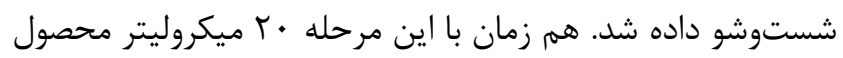

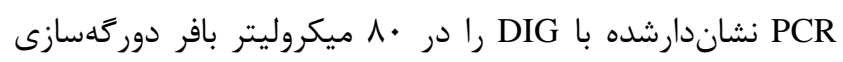

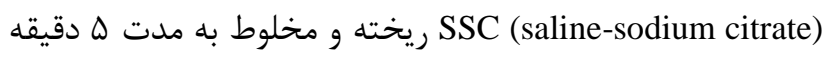

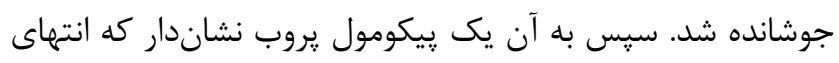

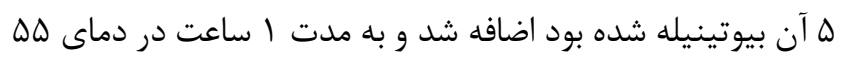

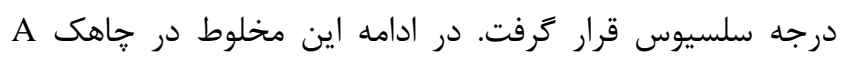

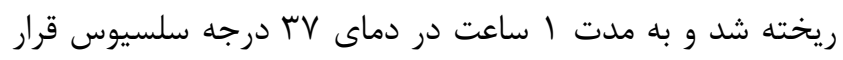

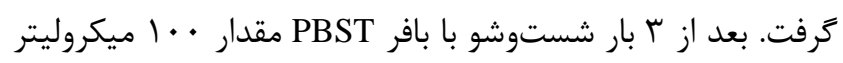

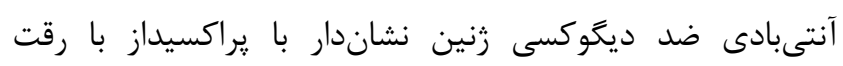

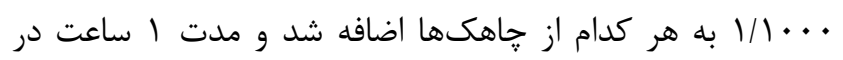

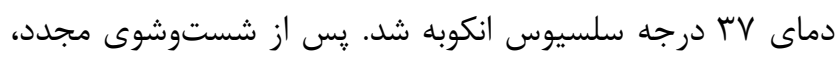

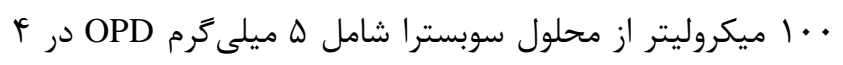

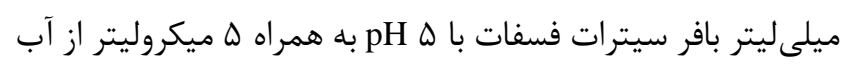

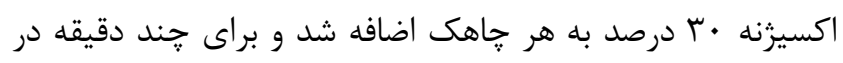

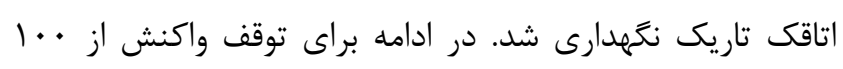

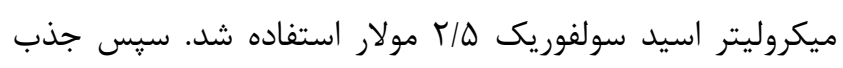

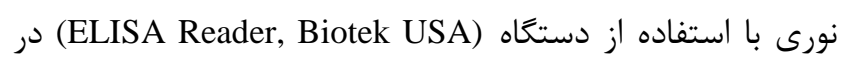
طول موج بو نو نانومتر خوانده شد.

تعيين حداقل غلظت زنومى قابل تشخيص با روش روش mecA با استفاده از محصولات PCR-ELISA نشاندارشده

يس از تعيين غلظت محصول PCR زن mecA نشاندارشده،

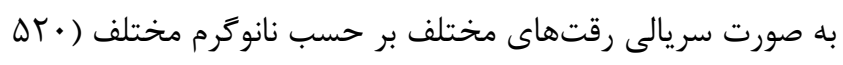

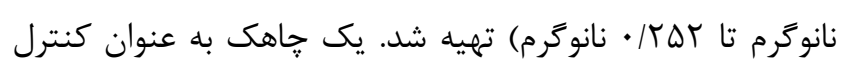

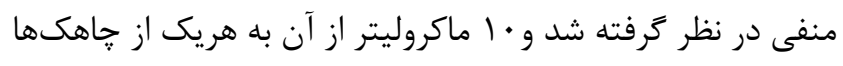

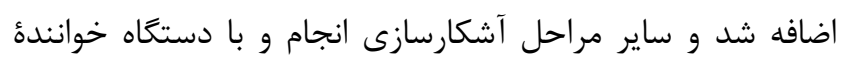

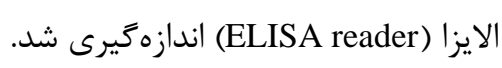

يس از مطمئنشدن از مطلوببودن يرايمرها با نرمافزارهاى

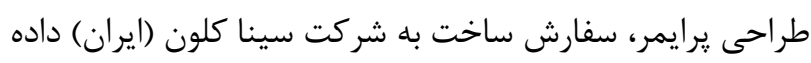

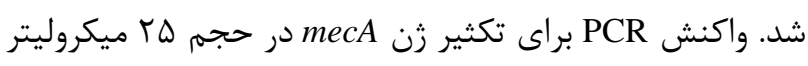

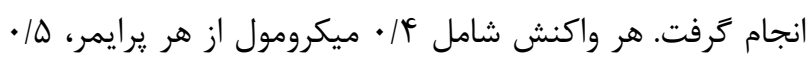
واحد از آنزيم Taq DNA polymerase (شر كت مت سيناكلون،

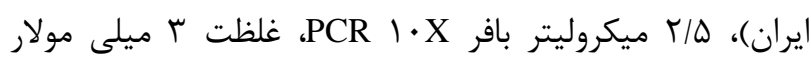
PMgCl PCR

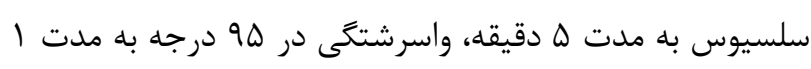

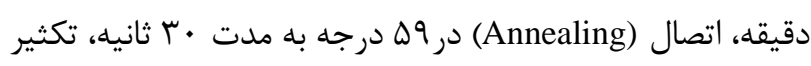

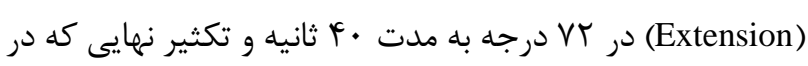

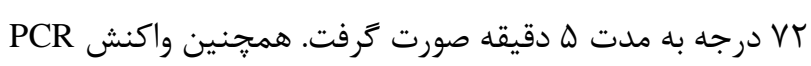

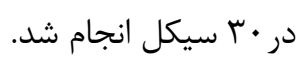

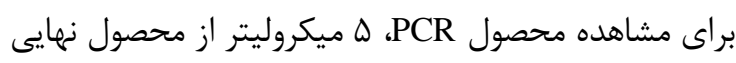

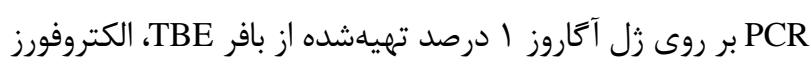

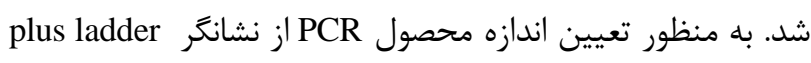

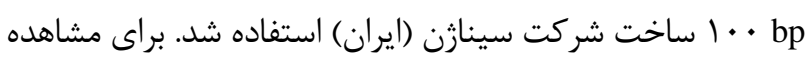

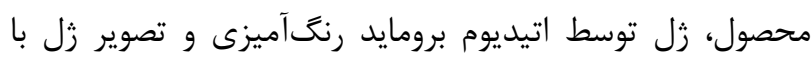

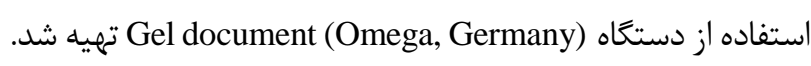
در اين تحقيق به منظور تأبيد زن تكثيريافته و براى شناسايى محصول PCR يروب طراحى شد (جدول (1). يروب با استفاده از نرم

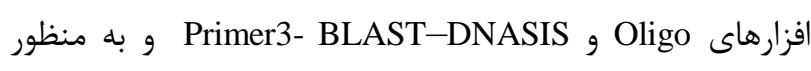

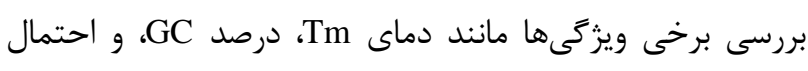

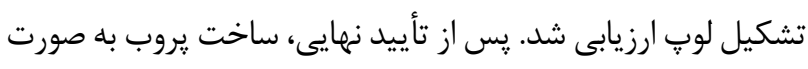

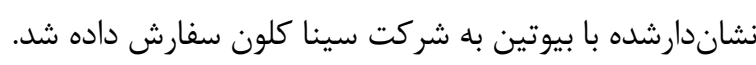

\section{نشانداركردن محصول PCR زنومى به وسيلة DIG-dUTP}

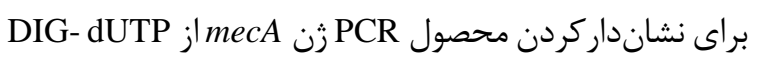

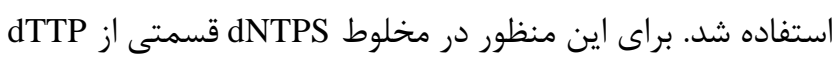

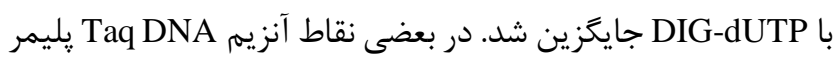

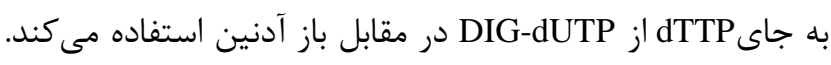
نسبت dTTP: DIG-dUTP استفادهشده זّ:ا بود. علاوه بر نمونه

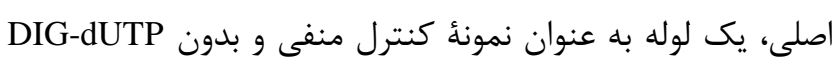

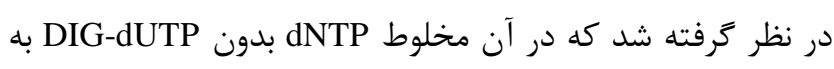

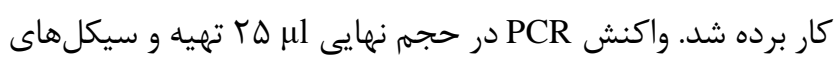
حرارتى مانند قبل در نظر كرفته شد.

PCR-ELISA

براى اين منظور ه ميكروليتر استريتواويدين با ه9 ميكروليتر

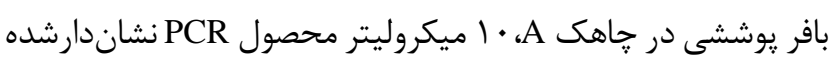


تكثير زن mecA در باكترى /ستافيلوكوكوس /ورئوس شده است.

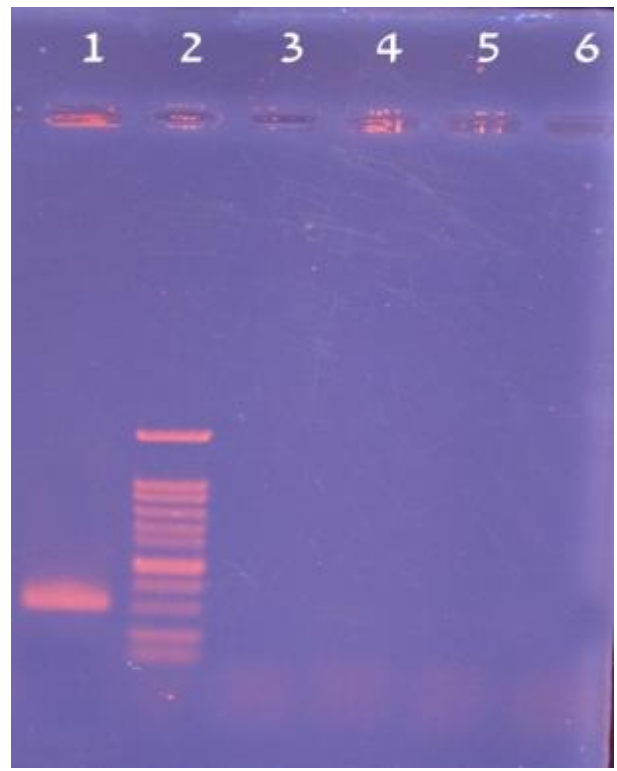

شكل ا. بررسى اختصاصيت واكنش PCR

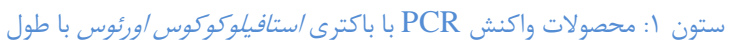

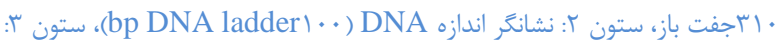

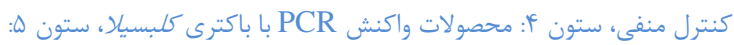

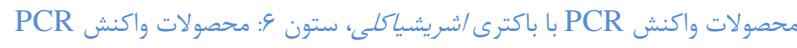
با باكترى باسيلوس سوبتليس اكتون

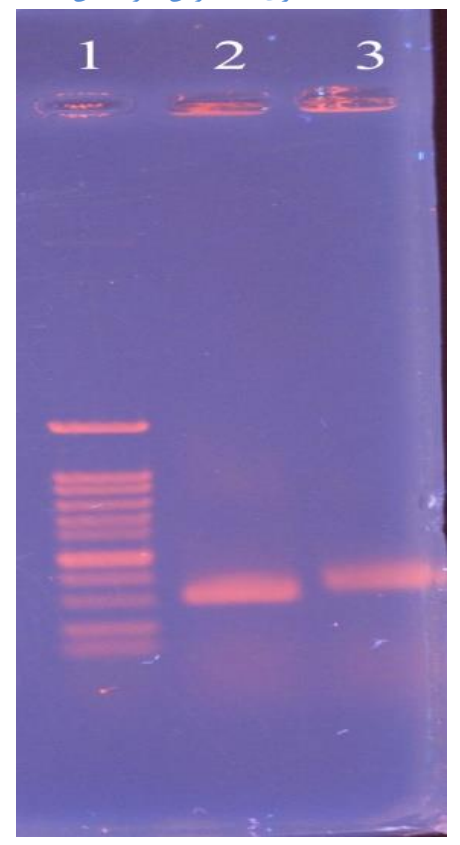

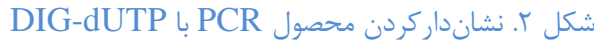

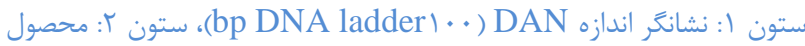
نشاندارنشده، ستون זّ: محصول PCR نشاندار شده P PCR

\section{PCR-ELISA تعيين ميزان اختصاصيت روش}

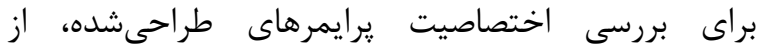
باكترىهاى كلبسيلا، باسيلوس سوبتليس و /شريشياكلى استفاده شد و آزمون PCR و سيس PCR-ELISA با آنها ارزيابى شد. تشخيص نمونه هاى بالينى با استفاده از روش PCR-ELISA

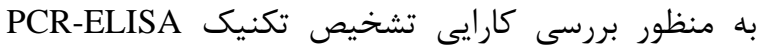

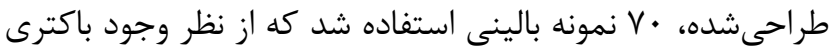
استافيلوكوكوس اورئوس مثبت تشخيص داده شدند. نمونههاى مذكور از كشت خون، ادرار و زخم مراجعه كنند كان به آزمايشكاههاى

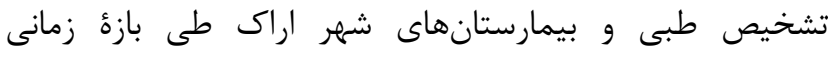

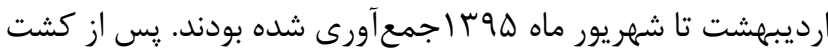
مجدد سويههاى جداشده، هويت باكترىها با روشهاى إستاى استاندارد شامل كاتالاز مثبت، DNase مثبت، رشد در مانيتول سالت آكار

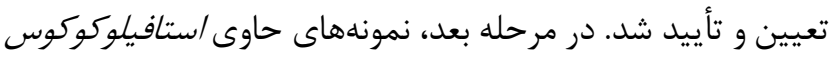

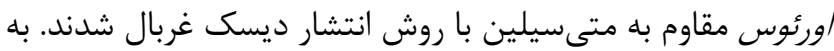

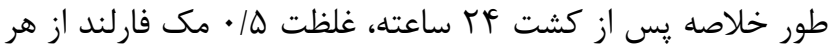

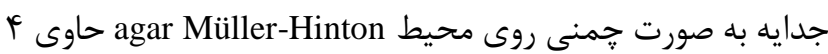

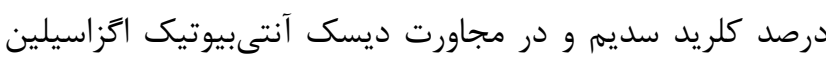

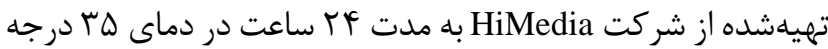

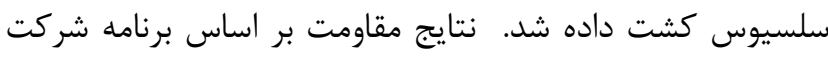
سازنده ديسك بررسى شد. سيس به منظور تعيين MIC براى نمونههاى مقاوم به متىسيلين، از روش آكار دايلوشن استفاده شد.

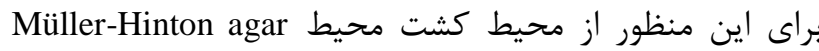

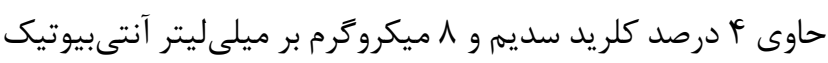

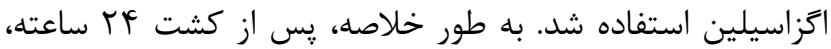
غلظت ف/ • مك فارلند از هر جدايه تهيه شد و تعداد • إباكترى

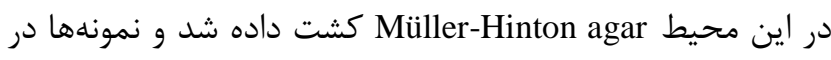

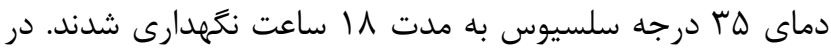

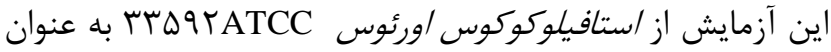

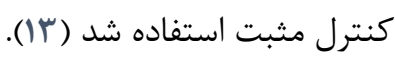

\section{يافتهها}

DNA زنومى باكترى استخر اج و غلظت آن . ㄷ ا نانوكرم در ميكروليتر تعيين شد. به منظور انجام واكنش PCR يرايمرهاى اختصاصى براى زن mecA طراحى شد كه با بهينه كردن واكنش PCR

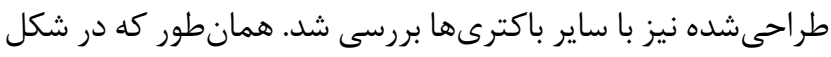

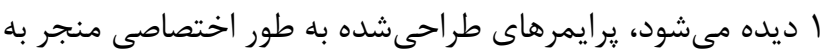


بيشتر از محصول PCR تكثيرشده با dNTPs عادى است. علت اين

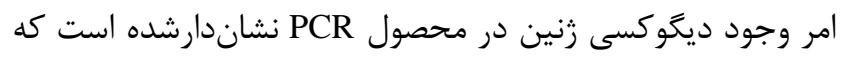

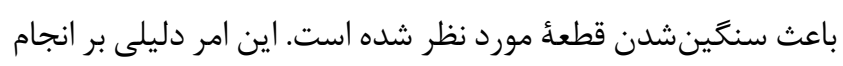
واكنش PCR در حضور DIG-dUTP است. يس از نشانداركردن محصولات PCR، آزمايش الايزا انجام

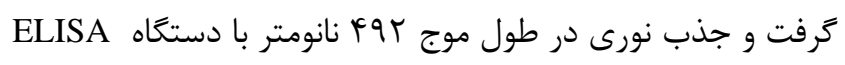

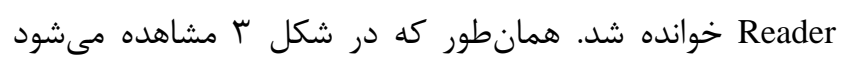

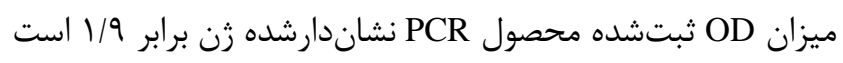
كه اين ميزان OD در حد حد قابل قبون محصول

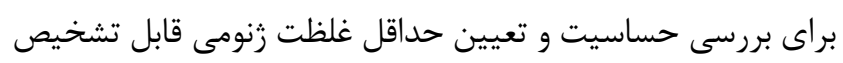

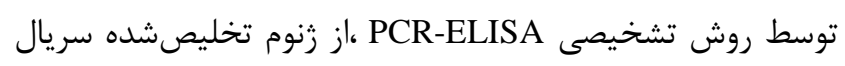

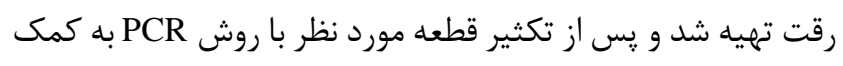

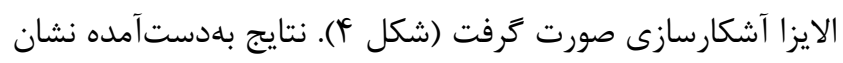

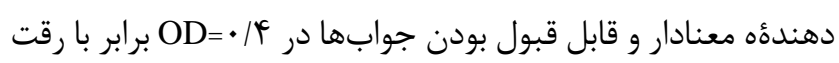

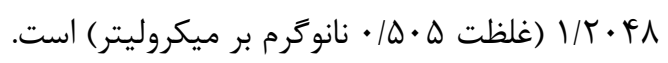

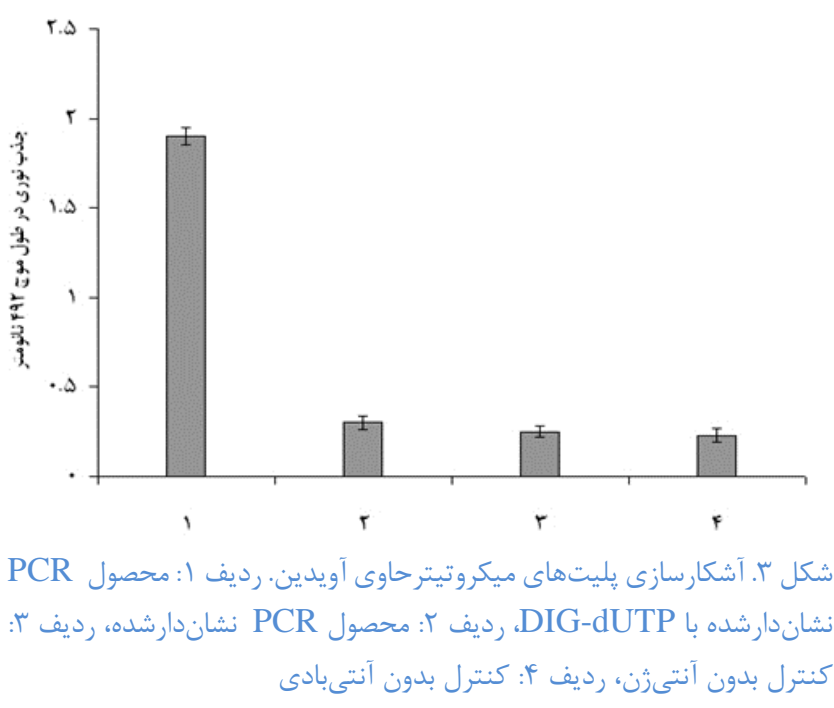

Dر ادامه به منظور نشانداركردن محصول PCR از

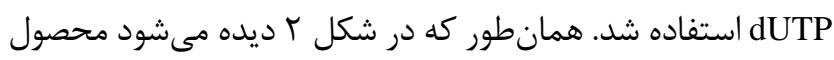

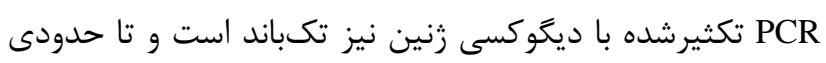

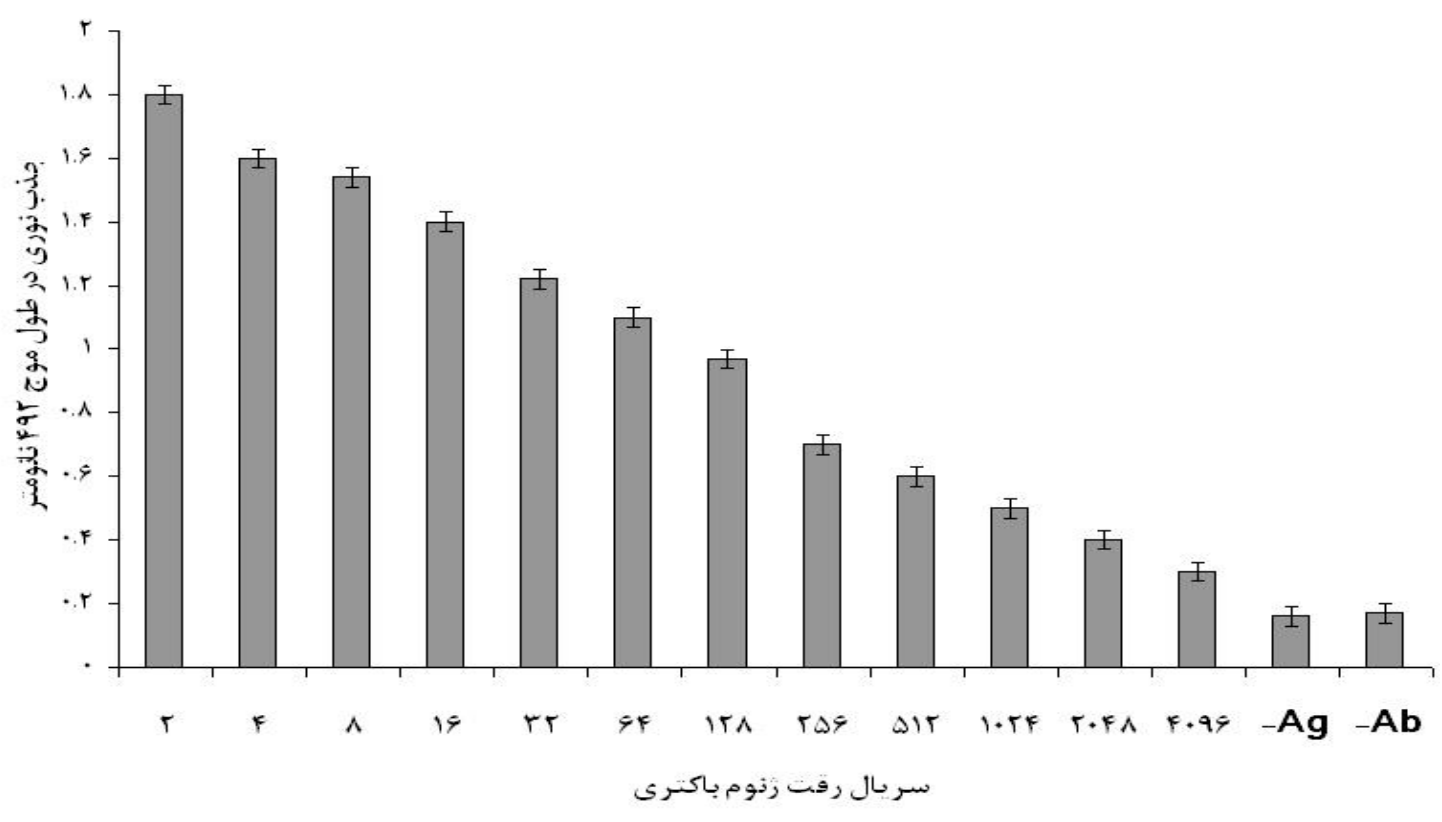

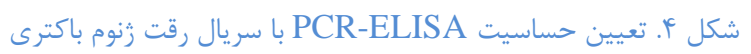

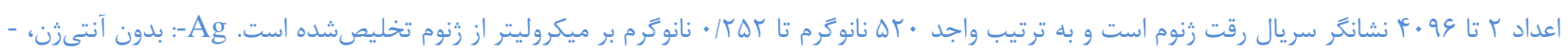
Ab

مطابق اطلاعات ارائه شده در شكل ه ارزيابى و ثبت PCR-ELISA

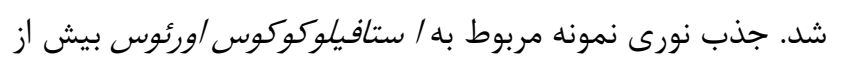

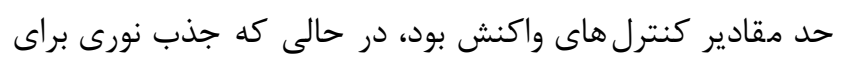
باكترىهاى ديكر كمتر از كنترل واكنش بود.
اختصاصيت روش تشخيصى نيز با بهكاركيرى ساير باكترىها

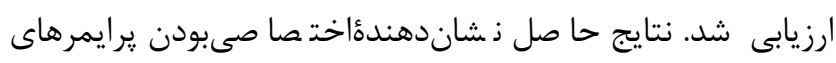

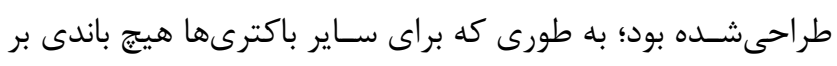

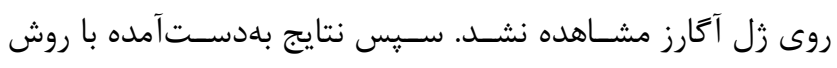




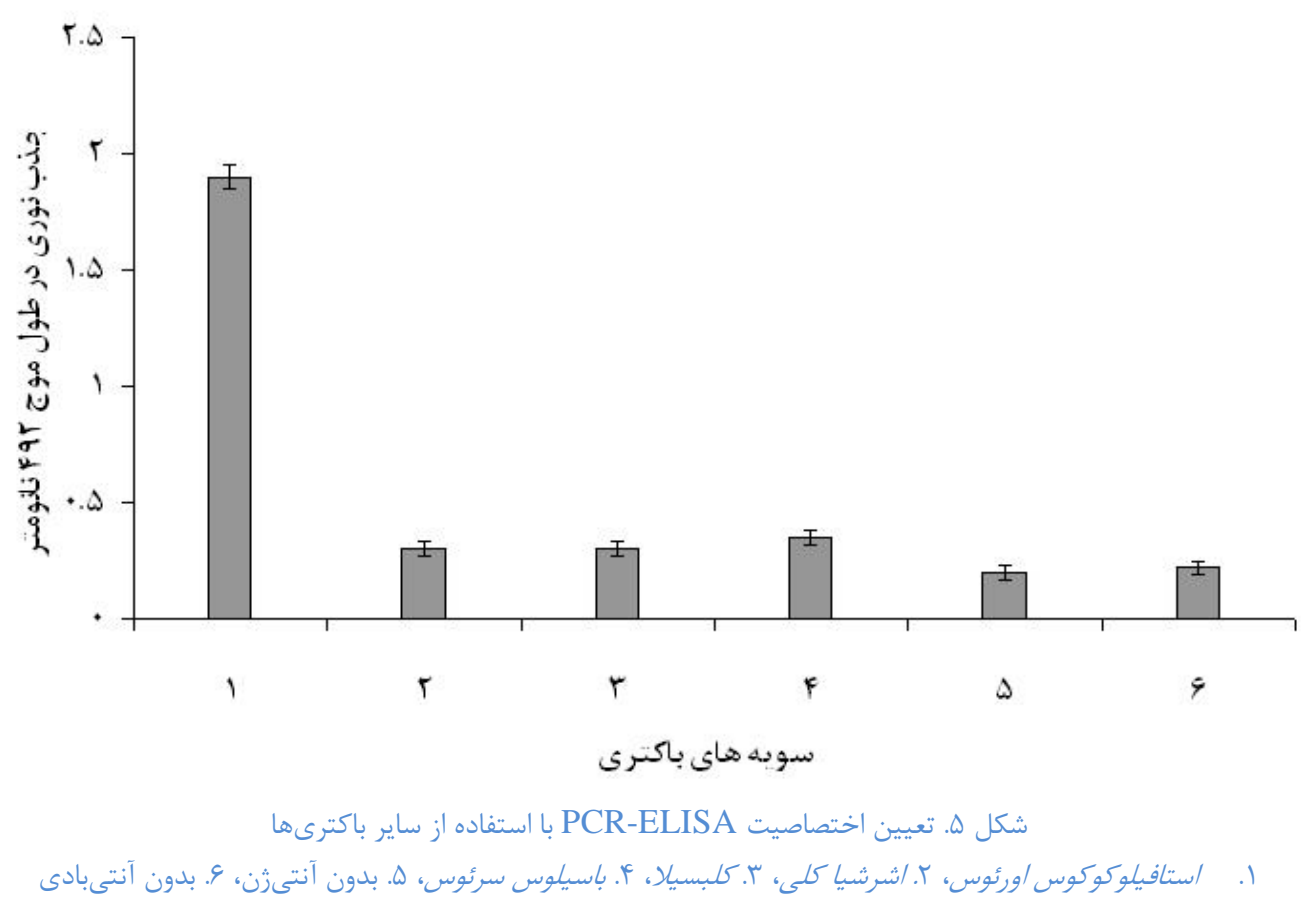

باكترى تغييرات زنتيكى زيادى را متحمل شده است. از آنجايى كه

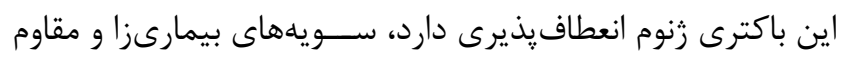

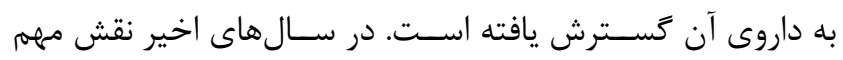

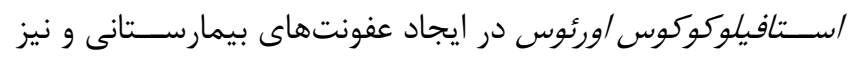
جامعه منجر به افزايش تحقيقات بسيارى بر روى اين باكترى شده إندادي

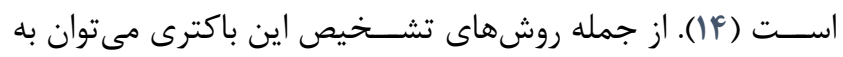

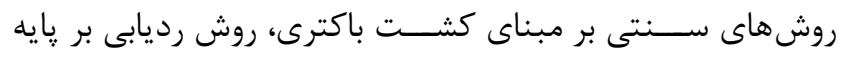

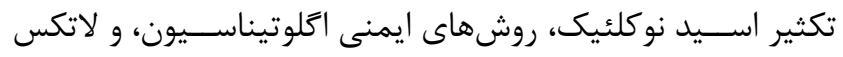

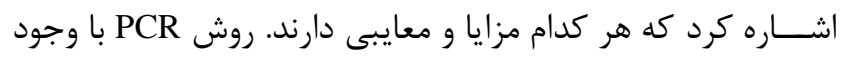

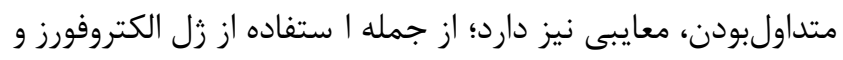

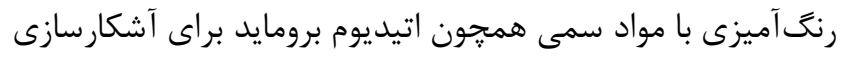

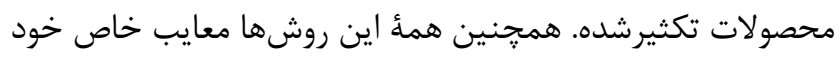

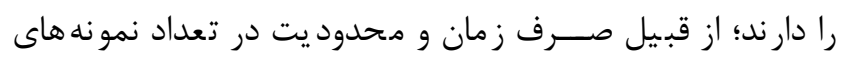

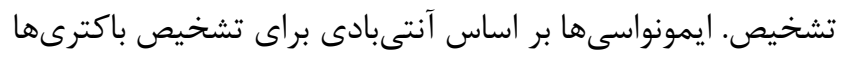

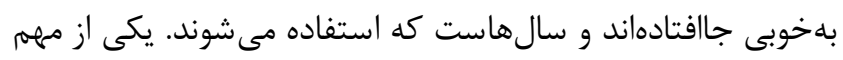

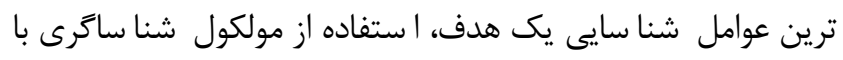

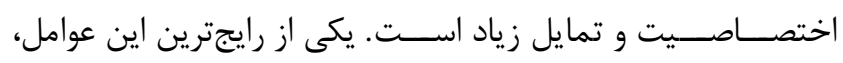

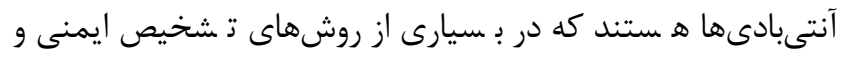

زيست حسكرها استفاده مىشوند (11).

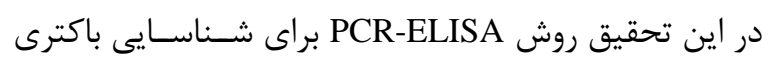

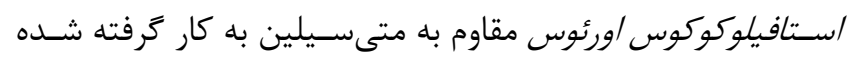

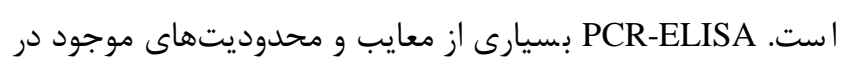

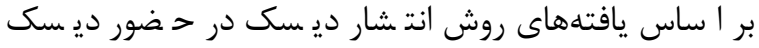

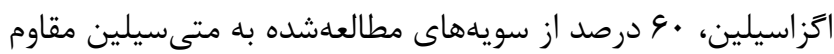

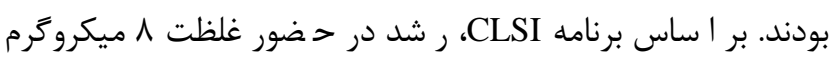

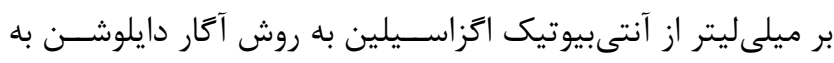

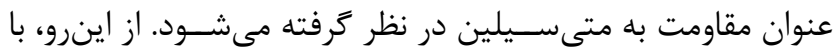

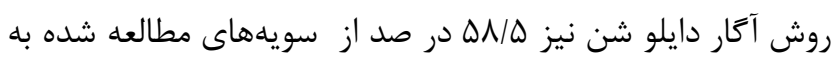

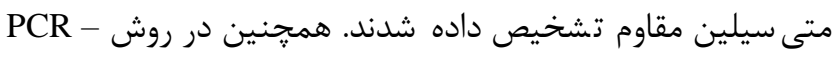
ELISA ع درصـد از سـويهها واجد زن مقاومت بودند (شـكل 9).

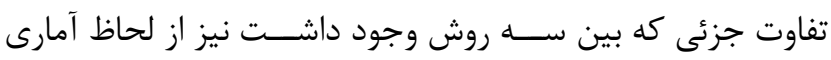

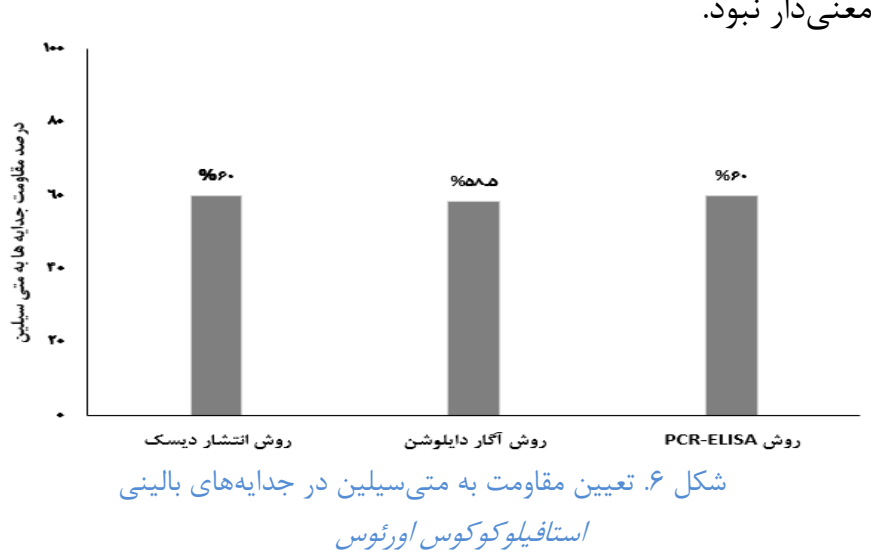

$$
\text { بحث و نتيجه }
$$

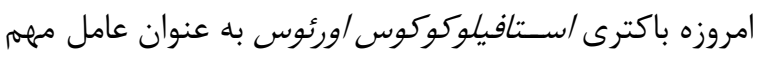

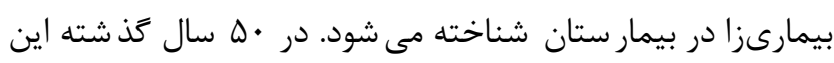




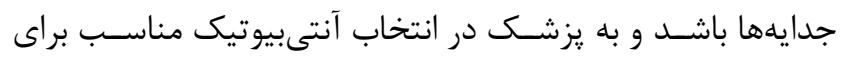

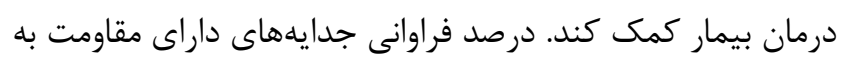

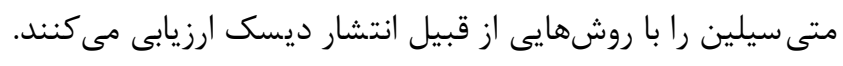

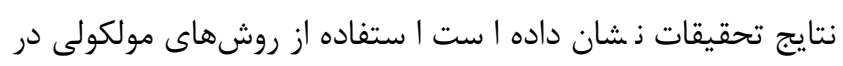

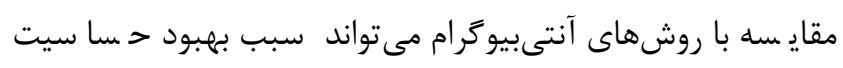

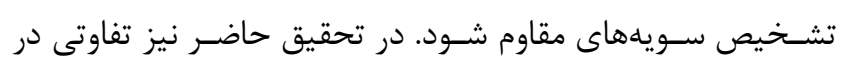

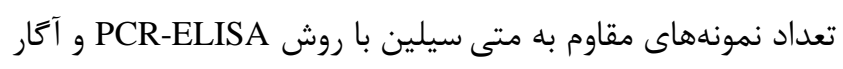

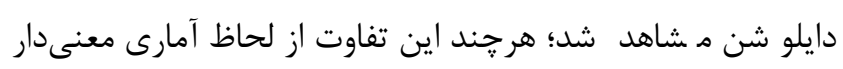

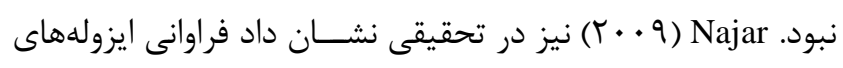

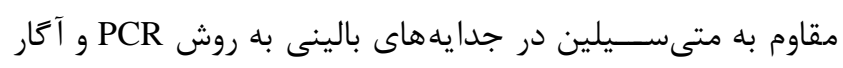

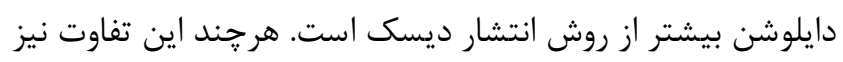
در تحقيق آنها از لحاظ آمارى معنى آندار نبود (19).

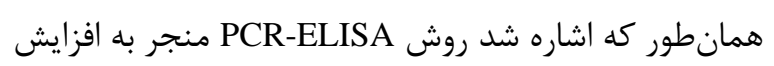

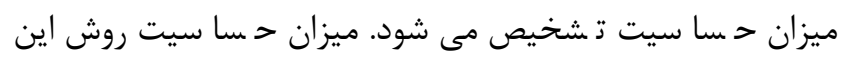

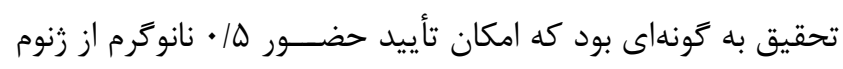

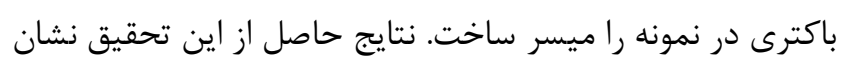

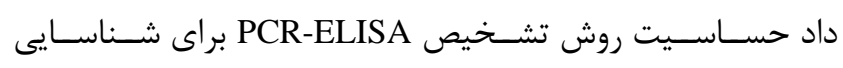

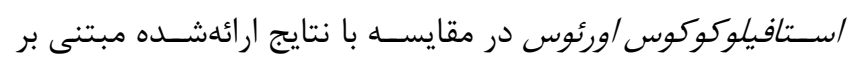

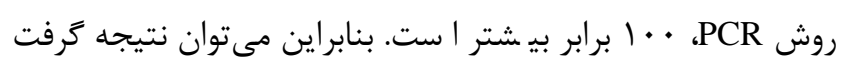

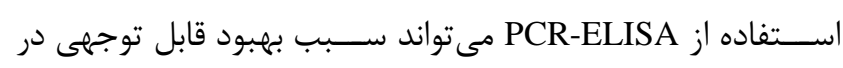

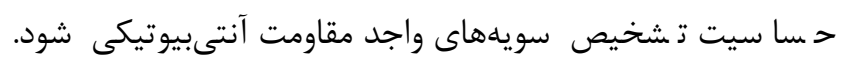

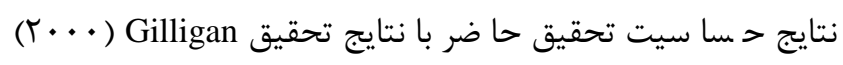

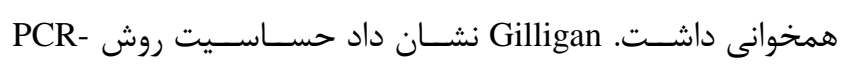

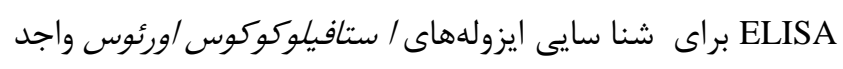

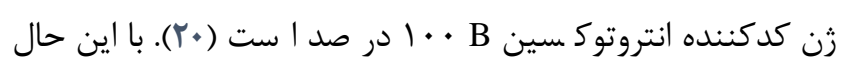

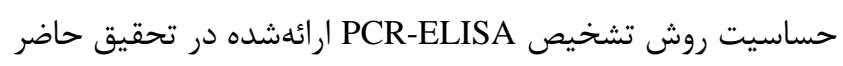
•ا برابر كمتر از حسا سيت تعريف شده در تحقيق Gilligan بود. ميزان اختصاصيت روش در هر دو تحقيق مشابه بود و تأييدكننده

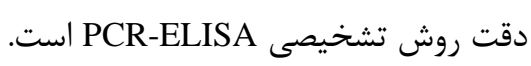

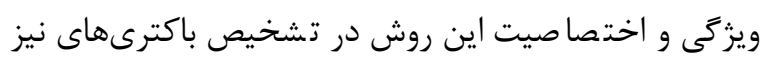

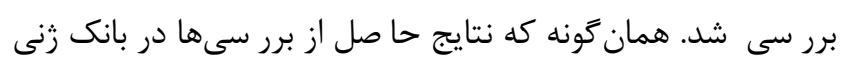

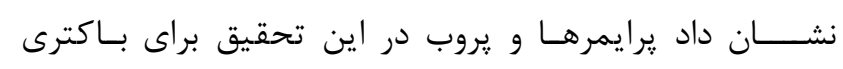

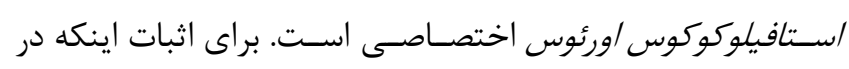

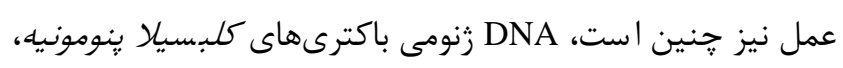

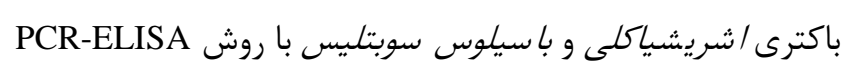

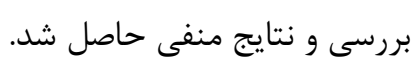

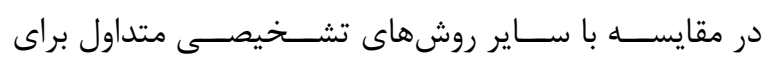
تشخيص جدايههاى /ستافيلوكوكوس /ورئوس مقاوم به متىسيلين،
روشهاى ديكر، از جمله PCR را بر طرف كرده ا ست، زيرا سرعت

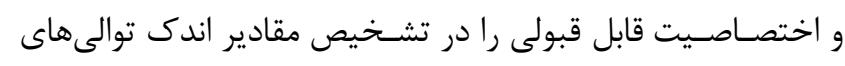

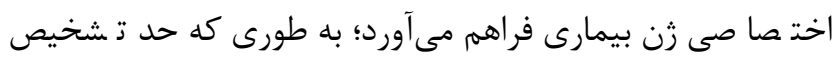

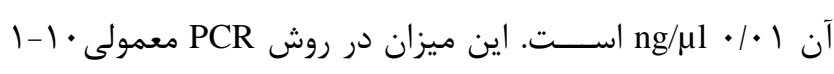

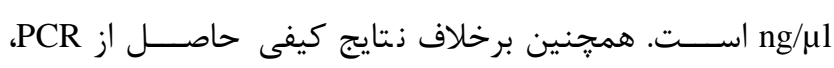

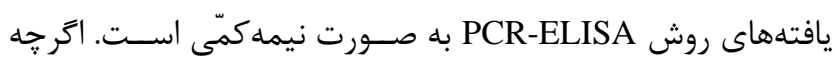

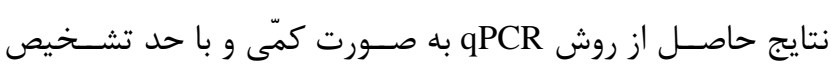

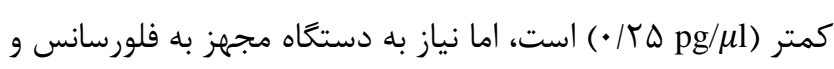

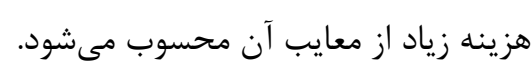

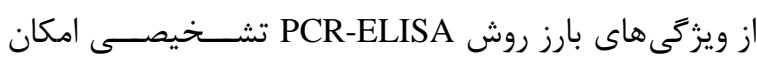

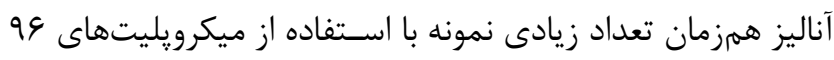

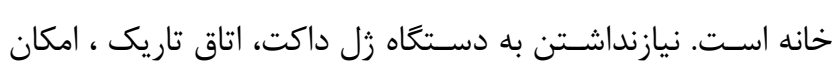

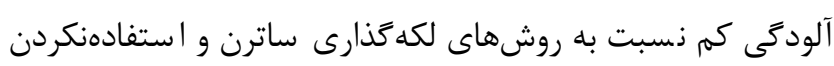

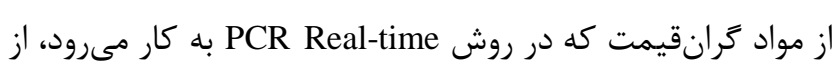

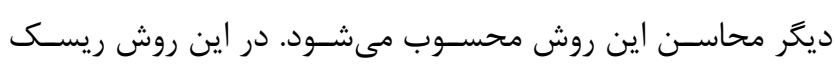

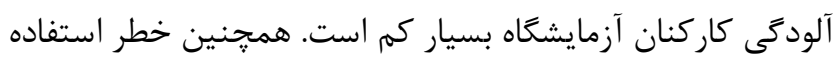

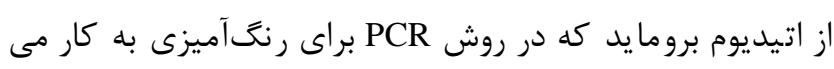
رود، وجود ندارد. در تحقيقاتى كه در زمينهٔ باكترىهايى خانواده/ستافيلوكوك

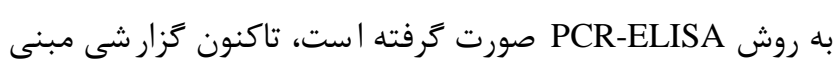

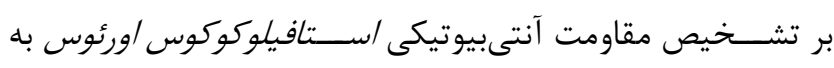

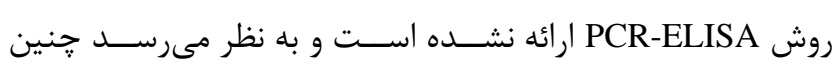

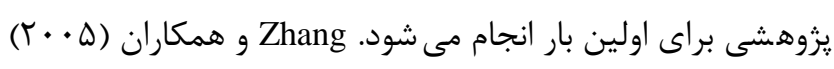

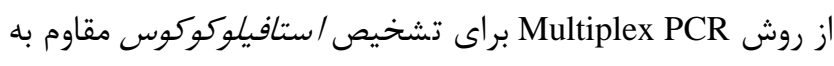

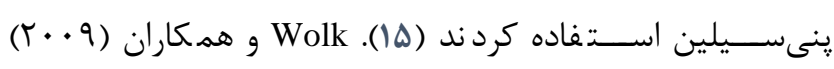

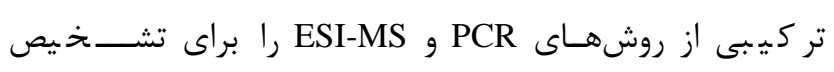

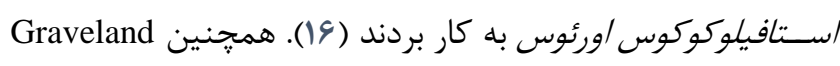

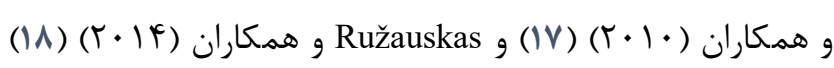

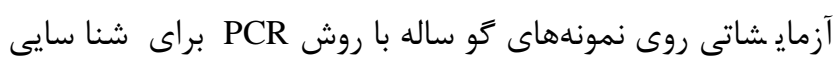

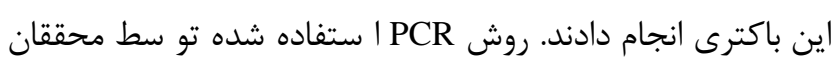

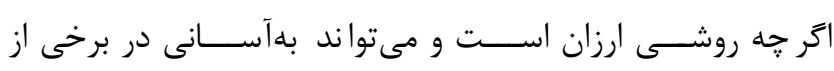

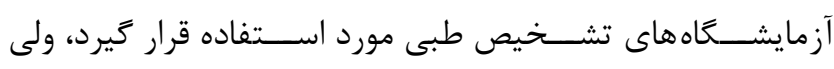

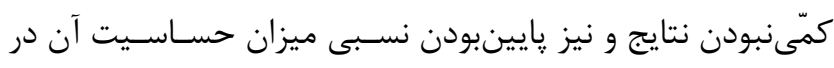

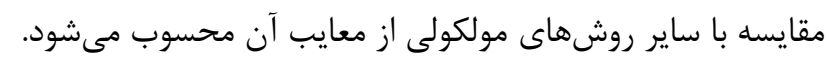

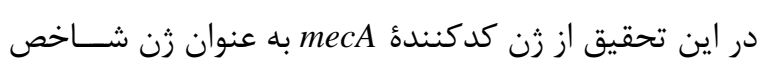

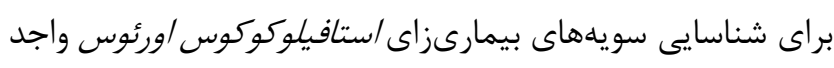

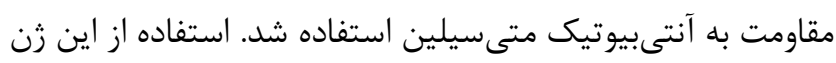

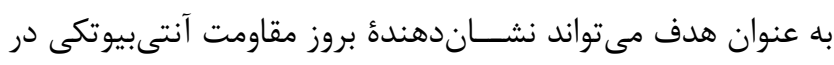




$$
\begin{aligned}
& \text { سياسَز'ارى }
\end{aligned}
$$

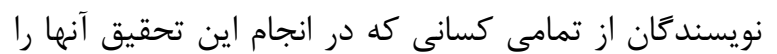

$$
\begin{aligned}
& \text { يارى كردند كمال تشكر و قدردانى را به عمل مى آورند. } \\
& \text { تعارض منافع } \\
& \text { بين نويسند كان تعارض در منافع گزارش نشده است. }
\end{aligned}
$$

\section{References}

1. Nazari MR, Sekawi Z, Sadeghifard N, Raftari M, Ghafourian S. Methicillin-Resistant Staphylococcus Aureus: A Systematic Review. Rev Med Microbiol. 2015; 26(1):1-7.

2. Laupland KB, Lyytikäinen O, Søgaard M, Kennedy KJ, Knudsen JD, Ostergaard C, et al .The Changing Epidemiology of Staphylococcus Aureus Bloodstream Infection: A Multinational Population-Based Surveillance Study. Clin Microbiol Infect. 2013; 19:465-471.

3. Tong SY, Davis JS, Eichenberger E, Holland TL, Fowler VG Jr. Staphylococcus Aureus Infections: Epidemiology, Pathophysiology, Clinical Manifestations, and Management. Clin Microbiol Rev. 2015; 28:603-661.

4. Chen CJ, Huang YC. New Epidemiology of Staphylococcus Aureus Infection in Asia. Clin Microbiol Infect. 2014; 20(7):605-623.

5. Hiramatsu K, Ito T, Tsubakishita S, Sasaki T, Takeuchi F, Morimoto Y, et al. Genomic Basis for Methicillin Resistance in Staphylococcus Aureus. Infect Chemother. 2013; 45:117-136.

6. Purrello SM, Garau J, Giamarellos E, Mazzei T, Pea F, Soriano A, et al. Methicillin-Resistant Staphylococcus Aureus Infections: A Review of the Currently Available Treatment Options. J Glob Antimicrob Resist. 2016; 7:178-186.

7. Tan TY, Corden S, Barnes R, Cookson B. Rapid Identification of Methicillin-Resistant Staphylococcus aureus from Positive Blood Cultures by Real-Time Fluorescence PCR. J Clin Microbiol. 2001; 39(12):4529-4531.

8. Martineau F, Picard FJ, Roy PH, Ouellette M, Bergeron MG. Species-Specific and Ubiquitous-DNA-Based Assays for Rapid Identification of Staphylococcus Aureus. J Clin Microbiol. 1998; 36: 618-623.

9. Chapin K , Musgnug M. Evaluation of Three Rapid Methods for the Direct Identification of

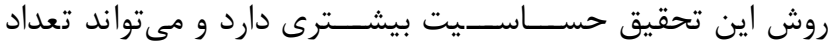

نسـخههاى اندكى از زن باكترى را تشـخيص دهد. اسـتفاده از زن

و طecA

تشخيصى اين روش شد؛ به طورى كه گونههاى ديگر در تحقيق با

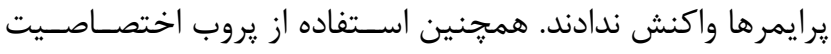

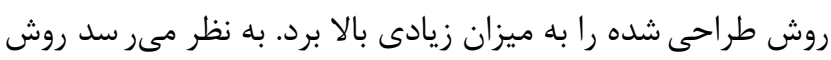

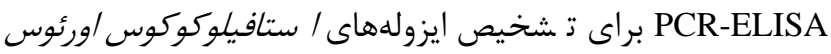
مقاوم به متىسيلين روش مناسب و قابل اعتمادى باشد.

Staphylococcus Aureus From Positive Blood Cultures. J Clin Microbiol. 2003; 41: 4324-4327.

10. Hamula CL, Zhang H, Li F, Wang Z, Le XC, Li XF. Selection and Analytical Applications of Aptamers Binding Microbial Pathogens. Trends Analyt Chem. 2011; 30: 1587-1597.

11. Lee JO, So HM, Jeon EK, Chang H, Won K, Kim YH. Aptamers as Molecular Recognition Elements for Electrical Nanobiosensors. Anal Bioanal Chem. 2008; 390: 1023-1032.

12. Sue MJ, Yeap SK, Omar AR, Tan SW. Application of PCR-ELISA in Molecular Diagnosis. BioMed Res Int. 2014; 2014.

13. Havaei SA, Halaji M, Vidovic S, Dillon Jo-AR, Karbalaei M, Ghanbari F, et al. Prevalence and Genotyping of Methicillin-Resistant and-Susceptible Staphylococcus Aureus Strains Isolated From Patients in a University Hospital, Isfahan, Iran. Jundishapur J Microbiol. 2017; 10: e13571.

14. Hamdan-Partida A, Sainz-Espuñes T, BustosMartínezJ. Characterization and Persistence of Staphylococcus Aureus Strains Isolated From the Anterior Nares and Throats of Healthy Carriers in a Mexican Community. J Clin Microbiol. 2010; 48: 1701-1705.

15. Zhang K, McClure JA, Elsayed S, LouieT, Conly JM. Novel Multiplex PCR Assay for Characterization and Concomitant Subtyping of Staphylococcal Cassette Chromosome Mec Types I to $\mathrm{V}$ in MethicillinResistant Staphylococcus Aureus. J Clin Microbiol. 2005; 43: 5026-33.

16. Wolk DM, Blyn LB, Hall TA, Sampath R, Ranken R, Ivy C,et al. Pathogen Profiling: Rapid Molecular Characterization of Staphylococcus Aureus by PCR/Electrospray Ionization-Mass Spectrometry and Correlation With Phenotype. J Clin Microbiol. 2009; 4737-3129.

17. Graveland H, Wagenaar JA, Heesterbeek H, Mevius D, Van Duijkeren E, Heederik D. Methicillin Resistant Staphylococcus Aureus ST398 in Veal Calf Farming: Human MRSA Carriage Related With Animal 


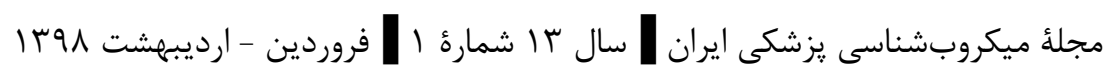

Antimicrobial Usage and Farm Hygiene. PLoS One. 2010; 5(6): e10990.

18. Ružauskas M, Couto N, Šiugždinienè R, Belas A, Klimienè I, Virgailis $\mathrm{M}$, et al. Occurrence and Characterization of Livestock-Associated MethicillinResistant Staphylococcus Aureus. Veterinarija ir Zootechnika. 2014; 66.

19. Najar PS, Azimian A, Mostafaei M, Siadat SD. Identification of Methicillin-Resistant Staphylococcus
Aureus by Disk Diffusion Method, Determination of MIC and PCR for MecA Gene. Pathobiol Res. 2009; 12:61-69.

20. Gilligan K, Shipley M, Stiles B, Hadfield TL, Ibrahim MS. Identification of Staphylococcus Aureus Enterotoxins A and B Genes by PCR-ELISA. Mol Cell Probes. 2000; 14:71-78. 